\title{
DIAGNOSIS OF INFLUENZA AND EVALUATION OF CLINICAL FINDINGS IN CHILD PATIENTS BEFORE THE COVID-19 PANDEMIC AND DURING THE PANDEMIC PERIOD
}

\author{
COVID-19 PANDEMI ÖNCESI VE PANDEMI DÖNEMINDE ÇOCUK HASTALARDA \\ INFLUENZA TANISI VE KLINIK BULGULARININ DEĞERLEŅDIRILMESi
}

\author{
Ömer OKUYAN ${ }^{1}$, Suna KIZILYILDIRIM², Adnan BARUTÇU, Özlem ERKAN IŞIK ${ }^{1}$ \\ ${ }^{1}$ İstanbul Atlas University, Faculty of Medicine, Department of Pediatrics, İstanbul, TURKEY \\ ¿ Süleyman Demirel University., Faculty of Pharmacy, Department of Pharmaceutical Microbiology, Isparta, TURKEY \\ ${ }^{3}$ Çukurova University, Faculty of Medicine, Department of Pediatrics, Adana, TURKEY
}

\begin{abstract}
Cite this article as: Okuyan Ö, Kızılyıldııım S, Barutçu A, Işık Erkan Ö. Diagnosis of Influenza and Evaluation of Clinical Findings
\end{abstract} in Child Patients before the Covid-19 Pandemic and During the Pandemic Period. Med J SDU 2021; 28(4): 613-619.

Öz

\begin{abstract}
Amaç
İnfluenza önemli bir halk sağlığı sorunudur. Özellikle çocuklarda, kronik hastalıkları bulunan ve bağışıklığı baskılanmış kişilerde ciddi akut solunum yolu enfeksiyonlarına sebep olurlar. Çalışmada çocuk hastalarda Covid-19 pandemi öncesi ve pandemi döneminde İnfluenza vakalarının sıklığı ve hastaların klinik bulgularının değerlendirilmesi amaçlandı.
\end{abstract}

\section{Gereç ve Yöntem}

Çalışmaya, 01.03.2019-11.03.2021 tarihleri arasında Atlas Üniversitesi Tıp Fakültesi Çocuk Acil ve Genel Çocuk Poliklinikleri'ne başvuran ve influeanza tanısı alan 0-18 yaş arasındaki hastalar dahil edildi. Hastaların klinik özellikleri, yatış oranı, komplikasyonlar, pandemi öncesi ve pandemi dönemindeki sıklığı aylara göre dağılımı incelendi.

\section{Bulgular}

Olguların \%55.6'sı ( $n=594)$ erkek, \%44.4'ü $(n=475)$ kız idi. Çalışma toplamda 1069 hasta ile tamamlan- dı. Çalışma sonucunda en fazla görülen semptomlar sırasıyla ateş (\%96.5), öksürük (\%51), halsizlik (\%42) ve burun akıntısı (\%30.8) idi. Hastaların \%93.2'si Covid-19 pandemi öncesi döneme aitti. İnfluenza virusunun Ocak ayında pik yaptığı ve Covid-19 pandemi sürecinde İnfluenza B tipinin daha sık görüldüğü saptandı.

\section{Sonuç}

Sonuç olarak, ilk Covid-19 vakasının görüldüğü tarihten itibaren alınan tedbirlerle İnfluenza'nın azaldığı görüldü.

Anahtar Kelimeler: Infuenza A, İnfluenza B, Semptomlar, Covid-19, Pandemi.

\section{Abstract}

\section{Objective}

Influenza is an important public health problem. They cause severe acute respiratory tract infections, especially in children, people with chronic diseases and immunosuppressed individuals. The aim of the study

Sorumlu yazar ve iletişim adresi /Responsible author and contact address: Ö.O. / dmemhs@gmail.com Müracaat tarihi/Application Date: 14.07.2021 • Kabul tarihi/Accepted Date: 12.11.2021 ORCID IDs of the authors: Ö.O: 0000-0002-1614-6149; S.K: 0000-0002-1039-8556; A.B: 0000-0001-8930-1122; Ö.E.I: 0000-0002-1455-3154 
was to evaluate the frequency of Influenza cases and the clinical findings of the patients before the Covid-19 pandemic and during the pandemic period.

\section{Material and Methods}

Patients aged 0-18 years, who applied to Atlas University Medical Faculty Pediatric Emergency and General Pediatric Polyclinics between 01.03.2019 and 11.03.2021 and were diagnosed with influenza, were included in the study. The clinical features of the patients, the rate of hospitalization, complications, the frequency before and during the pandemic, distribution by months were examined.

\section{Results}

$55.6 \%(n=594)$ of the cases were male and $44.4 \%$ $(n=475)$ were female. The study was completed with a total of 1069 patients. As a result of the study, the most common symptoms were fever (96.5\%), cough (51\%), fatigue (42\%) and nasal discharge (30.8\%). $93.2 \%$ of the patients belonged to the pre-Covid-19 pandemic period. It was determined that influenza virus peaked in January and influenza B type was seen more frequently during the Covid-19 pandemic period.

\section{Conclusion}

As a result, it was seen that Influenza decreased with the measures taken since the first Covid-19 case was seen.

Keywords: Influenza A, Influenza B, Symptoms, Covid-19, Pandemic

\section{Introduction}

Influenza is an infectious disease that causes serious complications and even death, especially in children and people with chronic diseases (1). The World Health Organization (WHO) estimates that there are approximately 1 billion cases of Influenza worldwide, 290,000 to 650,000 Influenza -related deaths, and 3-5 million cases of serious illness (especially in children, the elderly, and immunosuppressed persons) $(2,3)$. Influenza causes acute respiratory tract infections (ARTIs) that result in flu, fever, runny nose, cough, myalgia, headache and sometimes even death (4). ARTIs can have a serious course in childhood and constitutes 20 percent of deaths in children under 5 years of age (5). Influenza A/Influenza B (InfA/InfB) viruses are the most common causes of seasonal flu outbreaks in humans. Generally, the InfB virus is responsible for $15-30 \%$ of total Influenza infections and does not cause a pandemic. InfA virus is often responsible for seasonal Influenza epidemics and pandemic outbreaks due to frequent genetic mutations and inter-subtype reclassification (6).

Viral pneumonia cases are extremely common in the community. The viral infection rate in communityacquired pneumonia is approximately $25 \%$ (7). Severe acute respiratory syndrome coronavirus-2 (SARS-CoV-2) and Influenza are viruses that can cause pneumonia $(8,9)$. Seasonal Influenza is one of the important public health problems affecting approximately $5-10 \%$ of adults worldwide, and is a cause of serious morbidity and mortality, especially in high-risk groups (10). Patients with Influenza infection usually present with cough, fever, headache, weakness, myalgia, runny nose and sweating. The same symptoms tend to be seen in patients without Influenza pneumonia, but dyspnea is more common in patients with pneumonia (9). Since the outbreak of the Covid-19 pandemic, cases related to SARSCoV-2 and InfA coinfection have been reported from various countries (11). The WHO reported similar and different features of Covid-19 and Influenza in its statement dated March 17, 2020, and it was stated that both diseases had similar symptoms (12). In addition, there are studies reporting that clinical and radiological differential diagnosis is not made in cases with InfA and Covid-19 co-infection (13).

At the end of 2019, various measures have been taken around the world, with the spread of the Covid-19 pandemic all over the world, increasing the health burden, causing very serious contagiousness and clinically fatal pneumonia and acute respiratory distress syndrome. These measures are nonpharmacological measures (NPM), including social distance, hygiene, masks, as well as the closure of places such as cafes, bars, restaurants, where people stay and move collectively, and schools. It has been reported that serious reductions in most of the viruses transmitted by droplets are observed thanks to NPM (14).

In this study, it was aimed to evaluate the frequency and clinical findings of Influenza diagnosis before and during the Covid-19 pandemic period in Istanbul.

\section{Material and Methods}

A total of 1069 patients, aged 0-18 years, who applied 
to Atlas University Medicine Hospital General Pediatric Polyclinics and Pediatric Emergency Polyclinic with symptoms of fever and respiratory tract infection and diagnosed with Influenza between 01.03.201911.03.2021 were included in the study. The study was planned as a single-center Retrospective/Prospective study and the records of the patients were examined retrospectively. Non-interventional Ethics Committee approval was obtained from Atlas University Medical and Health Sciences Research Board (25.12.2020/01) for the study.

A pandemic was declared by the $\mathrm{WHO}$ on 11.03.2020, when the first Covid-19 case was seen in our country (15). In this context, the study was designed as preCovid-19 pandemic (01.03.2019-10.03.2020) and Covid-19 pandemic period (11.03.2020-11.03.2021). The files, computer records and discharge summary reports of all patients diagnosed with Influenza before and during the Covid-19 pandemic were retrospectively reviewed. Demographic features of the patients (age, gender), symptoms, clinical findings, antiviral or antibiotic treatment, length of stay in the hospital, and distribution of patients according to months were recorded.

Influenza test was performed in patients by fluorescent immunoassay method by looking for antigen. Nasopharyngeal swab samples were taken from the patients by entering through both nostrils with a swab and advancing up to the nasopharyngeal region, then the rods were rotated $360^{\circ}$. The samples were studied with the STANDART $F$ analyzer device manufactured by CD BIOSENSOR using the Influenza A/B FIA commercial kit. This method; It is a fluorescence immunoassay method that determines the presence of Influenza A (H1N1) and Influenza B (TAIWAN). Patients who were positive for InflA and InfB as a result of the test were recorded.

\section{Statistical Analysis}

SPSS (IBM Corp. Released 2017. IBM SPSS Statistics for Windows, Version 25.0. Armonk, NY: IBM Corp.) Statistical package program was used to evaluate the demographic and clinical characteristics of patients diagnosed with Influenza. Variables were expressed as mean \pm standard error, median, 25 quartiles, 75 quartiles, percentage and frequency. Variables were evaluated after controlling for normality and homogeneity of variances (Shapiro Wilk and Levene Test). Continuous variables were evaluated with the Mann-Witney $U$ and Kruskal Wallis tests. Categorical variables were analyzed with Fisher's Exact Test and Chi-Square test. In cases where the expected frequencies were less than $20 \%$, evaluation was made with the "Monte Carlo Simulation Method" to include these frequencies in the analysis. A $p$ value of $<0.05$ was accepted for the significance level of the tests.

\section{Results}

A total of 1069 patients diagnosed with Influenza were evaluated in the study. InfA was defined in 772 patients $(72.2 \%)$, while InfB was defined in 297 patients. When we examined the distribution of all patients according to symptoms, the most common symptoms were fever (96.5\%), cough (51\%), fatigue (42\%) and nasal discharge $(30.8 \%)$, while the least common symptoms were respiratory distress $(0.9 \%)$ and joint pain $(0.3 \%)$. Although patient symptoms were more common in InfA type, all symptoms were less common in patients diagnosed with InfB type. When the Influenza types and patients symptoms were examined, it was determined that the complaints of fatigue $(p=0.000)$ and vomiting $(p=0.044)$ were more common in the patients diagnosed with InfA, and the complaints of sore throat $(p=0.002)$ in the patients diagnosed with InfB. Symptoms of the patients are shown in Table 1. When the mean age of all patients was evaluated, the mean age of the patients diagnosed with InfB $(5.89 \pm 0.21)$ was found to be higher than the patients diagnosed with $\operatorname{Inf} A(4.33 \pm 0.13)(p=0.000)$.

In the study, it was seen that $93.2 \%(n=996)$ of the patients diagnosed with Influenza belonged to the pre-Covid-19 pandemic and in 73 patients during the pandemic period. It was observed that $55.6 \%(n=594)$ of the patients were male and $44.4 \%(n=475)$ were female, with a mean age of $4.76 \pm 0.11$ years. InfA was detected in the pre-pandemic period in 751 patients and in the pandemic period in 21 patients, whereas InfB was detected in 245 patients before the pandemic and in 52 patients during the pandemic period. It was observed that there was a significant increase in InfB infection during the Covid-19 period $(p=0.000)$. In addition, there was a significant increase in the use of antibiotics $(p=0.01)$ during the Covid-19 period (Table 2). 41 of the patients diagnosed with Influenza had chronic diseases.

In the study, when the distribution of patients diagnosed with Influenza before the Covid-19 pandemic period was examined, it was determined that it peaked in January with a rate of $50.7 \%$, and it was seen in November with a rate of $0.9 \%$ at least. In the Covid-19 pandemic period, 15.3\% Influenza was diagnosed only in March, and no Influenza cases were seen in other months during the study. However, before the Covid-19 pandemic period, the most common type 


\begin{tabular}{|l|c|c|c|c|}
\hline & $\begin{array}{c}\text { Influenza A } \\
\mathbf{N}(\%) \\
\mathbf{7 7 2}(\mathbf{7 2 . 2 \% )}\end{array}$ & $\begin{array}{c}\text { Influenza B } \\
\mathbf{N}(\%) \\
\mathbf{2 9 7}(\mathbf{2 7 . 8 \% )}\end{array}$ & $\begin{array}{c}\text { Total } \\
\mathbf{N}(\%) \\
\mathbf{1 0 6 9}(\mathbf{1 0 0 \% )}\end{array}$ & $\mathbf{p}$ \\
\hline Fever & $749(72.6 \%)$ & $283(27.4 \%)$ & $1032(100 \%)$ & 0.165 \\
\hline Cough & $402(73.8 \%)$ & $143(26.2 \%)$ & $545(100 \%)$ & 0.250 \\
\hline Fatigue & $359(80.0 \%)$ & $90(20.0 \%)$ & $449(100 \%)$ & $\mathbf{0 . 0 0 0}$ \\
\hline Nasal Discharge & $239(72.6 \%)$ & $90(27.4 \%)$ & $329(100 \%)$ & 0.835 \\
\hline Vomiting & $102(79.7 \%)$ & $26(20.3 \%)$ & $128(100 \%)$ & $\mathbf{0 . 0 4 4}$ \\
\hline Sore Throat & $72(60.5 \%)$ & $47(39.5 \%)$ & $119(100 \%)$ & $\mathbf{0 . 0 0 2}$ \\
\hline Headache & $41(75.9 \%)$ & $13(24.1 \%)$ & $54(100 \%)$ & 0.532 \\
\hline Body pain & $29(70.7 \%)$ & $12(29.3 \%)$ & $41(100 \%)$ & 0.829 \\
\hline Diarrhea & $34(85.0 \%)$ & $6(15.0 \%)$ & $40(100 \%)$ & 0.066 \\
\hline Nausea & $16(72.7 \%)$ & $6(27.3 \%)$ & $22(100 \%)$ & 0.957 \\
\hline Stomachache & $14(66.7 \%)$ & $7(33.3 \%)$ & $21(100 \%)$ & 0.566 \\
\hline Respiratory distress & $9(90.0 \%)$ & $1(10.0 \%)$ & $10(100 \%)$ & 0.207 \\
\hline Joint pain & $2(66.7 \%)$ & $1(33.3 \%)$ & $3(100 \%)$ & 0.830 \\
\hline & & & & \\
\hline
\end{tabular}

in January 2020 was InfA (61.9\%). InfB subtype was statistically higher than InfA in February 2020 (36.0\%) before the Covid-19 pandemic period and in March $2020(40.7 \%)$ during the pandemic period $(p=0.000)$.

\section{Discussion}

Influenza and Covid-19, both of which are respiratory diseases, have very similar symptoms, but there are different epidemiological, laboratory and clinical findings that distinguish the two diseases from each other. One of the most important differences between the two diseases is that Influenza shows seasonal characteristics and flu epidemics in countries in the Northern Hemisphere usually start in October and end in March. However, such a seasonal distribution has not been observed in the Covid-19 epidemic so far, on the contrary, there have been significant increases in the number of cases in many countries of the world, including our country, due to the relaxation of the measures (16).

Both Influenza and Covid-19 may present with symptoms such as fever, chills, cough, shortness of breath, feeling of tiredness and joint pains, sore throat, runny nose, and the first symptom in Covid-19 patients may be diarrhea, decrease or loss of sense of taste and smell (17).
In this study, it was aimed to evaluate the frequency and clinical findings of Influenza diagnosis before and during the Covid-19 pandemic period in Istanbul. As a result of the analysis of the data obtained from the study, it was observed that the peak of Influenza occurred in January. InfA was defined in 772 patients (72.2\%), while InfB was defined in 297 patients. The most common symptoms were fever (96.5\%), cough (51\%), fatigue (42\%) and nasal discharge (30.8\%). Influenza was seen the most in January (50.7\%) and the least in November (0.9\%). Gültekingil (18) reported the peak of Influenza as the end of December in his study. In line with the findings of our study, in the study conducted by Gültekingil, the most common Influenza type was A $(75.7 \%)$, male patients were affected more (45.3\%), and the first two most common symptoms were fever (94.2\%). and cough $(71.4 \%)$ were reported. Similar results were seen in the study conducted by Çiftçi et al. (19), and it was reported that the pandemic affected the preschool age group more and caused more frequent hospitalizations.

It has been emphasized that the disease can be fatal if the patients diagnosed with Influenza have chronic diseases, being pregnant, and risk factors such as old age (11). Gültekingil (17) reported in his study that hospitalized patients had underlying chronic diseases. In our study, in parallel with this study, it was observed 


\begin{tabular}{|c|c|c|c|}
\hline Variables & $\begin{array}{l}\text { Before the Covid-19 } \\
\text { pandemic, } n(\%)\end{array}$ & $\begin{array}{l}\text { During the Covid-19 } \\
\text { pandemic, } \mathrm{n}(\%)\end{array}$ & $\mathbf{p}$ \\
\hline $\begin{array}{l}\text { Gender } \\
\text { Female } \\
\text { Male } \\
\text { Total }\end{array}$ & $\begin{array}{l}447(94.1 \%) \\
549(92.4 \%) \\
996(93.2 \%)\end{array}$ & $\begin{array}{l}28(5.9 \%) \\
45(7.6 \%) \\
73(6.8 \%)\end{array}$ & 0.279 \\
\hline $\begin{array}{l}\text { Influenza } \\
\text { A } \\
\text { B } \\
\text { Total }\end{array}$ & $\begin{array}{l}751(97.3 \%) \\
245(82.5 \%) \\
996(93.2 \%)\end{array}$ & $\begin{array}{c}21(2.7 \%) \\
52(17.5 \%) \\
73(6.8 \%)\end{array}$ & 0.000 \\
\hline $\begin{array}{l}\text { Hospitalization } \\
\text { Absent } \\
\text { Present } \\
\text { Total }\end{array}$ & $\begin{array}{c}932(92.8 \%) \\
64(98.5 \%) \\
996(93.2 \%)\end{array}$ & $\begin{array}{l}72(7.2 \%) \\
1(1.5 \%) \\
73(6.8 \%)\end{array}$ & 0.081 \\
\hline $\begin{array}{l}\text { Elevated Creatine Kinase } \\
\text { Absent } \\
\text { Present } \\
\text { Total }\end{array}$ & $\begin{array}{c}973(93.3 \%) \\
23(88.5 \%) \\
996(93.2 \%)\end{array}$ & $\begin{array}{l}70(6.7 \%) \\
3(11.5 \%) \\
73(6.8 \%)\end{array}$ & 0.335 \\
\hline $\begin{array}{l}\text { Acute Respiratory Tract Infectio } \\
\text { Absent } \\
\text { Present } \\
\text { Total }\end{array}$ & $\begin{array}{l}872(93.6 \%) \\
124(90.5 \%) \\
996(93.2 \%)\end{array}$ & $\begin{array}{l}60(6.4 \%) \\
13(9.5 \%) \\
73(6.8 \%)\end{array}$ & 0.186 \\
\hline $\begin{array}{l}\text { Antibiotic usage } \\
\text { Absent } \\
\text { Present } \\
\text { Total }\end{array}$ & $\begin{array}{l}768(94.4 \%) \\
258(89.9 \%) \\
996(93.2 \%)\end{array}$ & $\begin{array}{c}44(5.6 \%) \\
29(10.1 \%) \\
73(6.8 \%)\end{array}$ & 0.01 \\
\hline $\begin{array}{l}\text { Oseltamivir } \\
\text { Absent } \\
\text { Present } \\
\text { Total } \\
\end{array}$ & $\begin{array}{c}11(84.6 \%) \\
985(93.3 \%) \\
996(93.2 \%)\end{array}$ & $\begin{array}{l}2(15.4 \%) \\
71(6.7 \%) \\
73(6.8 \%)\end{array}$ & 0.219 \\
\hline $\begin{array}{l}\text { Otitis Media } \\
\text { Absent } \\
\text { Present } \\
\text { Total }\end{array}$ & $\begin{array}{c}990(93.2 \%) \\
6(85.7 \%) \\
996(93.2 \%)\end{array}$ & $\begin{array}{l}72(6.8 \%) \\
1(14.3 \%) \\
73(6.8 \%)\end{array}$ & 0.433 \\
\hline $\begin{array}{l}\text { Age }(n=1069),(\text { Year) } \\
\text { (Mean } \pm \text { SD) }\end{array}$ & \multicolumn{3}{|c|}{$4.76 \pm 0.11$} \\
\hline $\begin{array}{l}\text { Hospitalization Length }(n=65) \text {, } \\
\text { (Day) (Mean } \pm \text { SD) }\end{array}$ & \multicolumn{3}{|c|}{$2.75 \pm 0.128$} \\
\hline
\end{tabular}

that $41(3.8 \%)$ of the patients had chronic diseases and $65(6.1 \%)$ were hospitalized.

In our study, $287(26.8 \%)$ patients were treated with antibiotics. We think that this situation is related to secondary bacterial infections. In addition, it was determined that there was a decrease in the complaints of fatigue $(p=0.009)$ and an increase in the use of antibiotics $(p=0.01)$ during Covid-19. However, no significant difference was observed in terms of these parameters before the Covid-19 pandemic period and during the pandemic period. However, a significant increase in InfB infection $(p=0.000)$ was observed during the Covid-19 pandemic period. However, it is thought that this situation is not related to Covid-19 as stated in the study of Blanton et al. (20). 
When we compared Influenza types with demographic data and clinical symptoms, it was determined that the complaints of fatigue $(p=0.000)$ and vomiting $(p=0.044)$ were more common in patients diagnosed with InfA, and sore throat $(p=0.002)$ in patients diagnosed with InfB. The mean age of patients diagnosed with InfB $(5.89 \pm 0.21)$ was found to be higher $(p=0.000)$ than patients diagnosed with InfA $(4.33 \pm 0.13)$. These findings were found to be compatible with the results of the study conducted by Tran et al. (21).

In our study, it was observed that $93.2 \%(n=996)$ of the patients belonged to the pre-Covid-19 pandemic. In line with the measures taken with the onset of the Covid-19 pandemic, Covid-19 cases were seen only in March 2020, but no Influenza cases were encountered until March 2021. We think that NPM was effective in the emergence of cases after March 2020, when the first Covid-19 case was seen in Turkey. Noh et al. (2020) reported that the Influenza season decreased from 40.9 weeks to 4-16.4 weeks with the application of NPM in South Korea (14). In the study of Ahmed et al. (22) it was shown that the Influenza epidemic decreased in case of maintaining social distance and the attack of the cumulative Influenza population decreased by $23 \%$ if social distance was maintained in the workplaces. It has also been reported that the reduction in the cumulative attack rate is more pronounced when combined with other pharmacological and non-pharmacological methods. In a study conducted in Hong Kong, it was found that NPM was associated with a decrease in the transmission of Covid-19 and significantly reduced the transmission of Influenza in the early period (23). NPM has been reported to significantly reduce the spread of seasonal Influenza. In addition, it was emphasized that it is important to take these precautions in places where a vaccine cannot be found in the early phase of the Influenza pandemic (24).

As a result, it was understood that NPM, which was taken with the Covid-19 pandemic, provided a serious reduction in the incidence of Covid-19 and Influenza, and even no cases were seen in some months. It has been seen that Influenza is a serious public health problem, and NPM is as important as pharmacological measures to prevent it. Even if the Covid-19 pandemic is over in the next period, we think that NPM should be implemented in our social life as much as possible.

\section{Conflict of Interest Statement}

The authors have no conflicts of interest to declare.

\section{Ethical Approval}

Ethics Committee approval was obtained from Atlas
University Medical and Health Sciences Research Board (25.12.2020/01) for the study.

\section{Funding}

This research did not receive any specific grant from funding agencies in the public, commercial, or not-forprofit sectors.

\section{References}

1. Antonova EN, Rycroft CE, Ambrose CS, Heikkinen T, Principi N. Burden of paediatric Influenza in Western Europe: a systematic review. BMC Public Health 2012;12:968.

2. Lampejo T. Influenza and antiviral resistance: an overview. Eur J Clin Microbiol Infect Dis 2020;13:1-8.

3. Alexander-Miller MA. Challenges for the Newborn Following Influenza Virus Infection and Prospects for an Effective Vaccine. Front Immunol 2020;11:568651.

4. Jung HE, He Lee HK. Host Protective Immune Responses against Influenza A Virus Infection. Viruses 2020; 12(5):504.

5. Shafik CF, Mohareb EW, Yassin AS, Amin MA, El Kholy A, El-Karaksy $\mathrm{H}$, ve ark. Viral etiologies of lower respiratory tract infections among Egyptian children under five years of age. BMC Infect Dis2012;12:350-8.

6. Jung HE, He Lee HK. Host Protective Immune Responses against Influenza A Virus Infection. Viruses 2020; 12(5):504.

7. Burk M, El-Kersh K, Saad M, Wiemken T, Ramirez J, Cavallazzi R. Viral infection in community-acquired pneumonia: A systematic review and meta-analysis. Eur Respir Rev 2016;25:178-88.

8. Guan WJ, Ni ZY, Hu Y, Liang WH, Ou CQ, He JX, et al. Clinical characteristics of coronavirus disease 2019 in China. N Engl J Med 2020;382:1708-20.

9. Cavallazzi R, Ramirez JA. Influenza and viral pneumonia. Clin Chest Med 2018;39:703-21.

10. Meşe S, Uyanik A, Ozakay A, Ozturk S, Badur S. Influenza surveillance in western Turkey in the era of quadrivalent vaccines: A 2003-2016 retrospective analysis. Hum Vaccin Immunother 2018;14:1899-908.

11. Yuki Kondo, Shinichi M, Ryo Yamashita, Takuya Ikeda. Coinfection with SARScov-2 and Influenza A virüs. BMJ Case Rep 2020;13(7): e236812.

12. World Health Organization (WHO). Influenza and COViD-19 - similarities and differences. [cited 17 March 2020]. Available from:https://www.who.int/news-room/q-a-detail/coronavirus-disease-Covid-19-similarities-and-differences-with-Influenza

13. Shuhei Azekawaa, Ho Namkoongb, Keiko Mitamurad, Yoshihiro Kawaokae, Fumitake Saitoa. Co-infection with SARS-cov-2 and Influenza A virüs. Idcases 2020;20:e00775.

14. Noh JY, Seong H, Yoon JG, Song JY, Cheong HJ, and Kim WJ. Social distancing against COVID-19: implication for the control of Influenza . Journal of Korean medical science 2020;35(19).

15. T.C. Sağlık Bakanlığı: COViD-19 Bilgilendirme Platformu. https://Covid19.saglik.gov.tr/TR-66494/pandemi.html.

16. Akova M. COViD-19 İnfluenza İlişkisi. Türk Tabipler Birliği COViD-19 Pandemisi Altıncı Ay Değerlendirme Raporu.

17. Centers for Disease Control and Prevention (CDC): Similarities and differences between flu and COVID-19. Retrieved From: https://www.cdc.gov/flu/symptoms/flu-vs-Covid19.htm

18. Gültekingil A. Clinical Features of 2017-2018 Seasonal Influenza Infection: A Single-Center Experience. Cocuk Acil ve Yogun Bakım 2018;5(3):119.

19. Çiftçi E, Tuygun N, Özdemir H, Tezer H, Şensoy G, Devrim I, and Doğru Ü. Clinical and epidemiological features of Turkish children with 2009 pandemic Influenza A (H1N1) infection: experience from multiple tertiary paediatric centres in Turkey. Scand J Infect Dis 2011;43:923-9. 
20. Blanton L, Alabi N, Mustaquim D, Taylor C, Kniss K, Kramer $\mathrm{N}$, et al. Update: Influenza activity in the united states during the 2016-17 season and composition of the 2017-18 Influenza vaccine. MMWR Morb Mortal Wkly Rep 2017;66(25);668-76

21. Tran D, Vaudry W, Moore D, Bettinger JA, Halperin SA, Scheifele, et al. Hospitalization for Influenza A Versus B. Pediatrics 2016;138.

22. Ahmed F, Zviedrite N, Uzicanin A. Effectiveness of workplace social distancing measures in reducing Influenza transmission: a systematic review. BMC Public Health 2018;18(1):518.

23. Cowling BJ, Ali ST, Ng TW, Tsang TK, Li JC, Fong MW, et al. Impact assessment of non-pharmaceutical interventions against coronavirus disease 2019 and Influenza in Hong Kong: an observational study. Lancet Public Health 2020;5(5):e279-88.

24. Saunders-Hastings P, Reisman J, Krewski D. Assessing the state of knowledge regarding the effectiveness of interventions to contain pandemic Influenza transmission: a systematic review and narrative synthesis. PLoS One 2016;11:e0168262. 